\title{
STRATEGI PENGEMBANGAN ASURANSI JIWA
}

\author{
DEVELOPMENT STRATEGY OF LIFE INSURANCE \\ Sulastri*)1, Amzul Rifin ${ }^{* *}$, dan Bunasor Sanim ${ }^{* * *}$ \\ ${ }^{*}$ PT Asuransi Jiwa TASPEN \\ Jl. Jend. Sudirman kav. 2 Jakarta 10220 \\ ${ }^{* *}$ Departemen Agribisnis, Fakultas Ekonomi dan Manajemen, Institut Pertanian Bogor \\ Jl. Kamper, Wing 4 Level 5, Kampus IPB Dramaga, Bogor 16680 \\ ${ }^{* * *}$ Sekolah Bisnis, Institut Pertanian Bogor \\ Jl. Raya Pajajaran, Bogor 16151
}

\begin{abstract}
Insurance is a financial institution that is engaged in the service field and a NonBank Financial Institution. The achievement of PT Asuransi Jiwa TASPEN is not maximal, due to the limitations of facilities, infrastructure, and human resources in the development of the market, but the opportunities of this company in achieving the targets set will be very large if it implements strategies that fit the factors it experiences. This study aims to identify and study the internal and external factors that affect the existence of PT Asuransi Jiwa TASPEN and to formulate appropriate strategic alternatives to be applied in this company. These internal and external factors strongly influence the company. With its strengths, weaknesses, opportunities and threats, the management must utilize SO strategy that harnesses its largest power to take advantage of opportunities. The SO alternative strategies include the strengthening of the partnerships with the government and availability of insurance programs to the needs of civil servants, development of marketing distribution, opening of the office channeling at the branch offices in order to anticipate market development, and improvement of the quality and quantity of human resources.
\end{abstract}

Keywords: alternative strategies, insurance, Asuransi Jiwa, SWOT

\begin{abstract}
Abstrak: Asuransi adalah salah satu lembaga keuangan yang bergerak di bidang jasa dan merupakan Lembaga Keuangan Non-Bank. Belum maksimalnya pencapaian target PT Asuransi Jiwa Taspen dikarenakan adanya keterbatasan sarana, prasarana, dan sumber daya manusia dalam pengembangan pasar, akan tetapi peluang perusahaan ini dalam pencapaian target yang ditetapkan akan sangat besar apabila diterapkan strategi yang sesuai dengan faktor-faktor yang dialami oleh perusahaan. Penelitian ini bertujuan mengidentifikasi dan mengkaji faktor-faktor internal dan eksternal yang memengaruhi eksistensi PT Asuransi Jiwa Taspen dan merumuskan alternatif strategi yang tepat dijalankan di PT Asuransi Jiwa Taspen. Faktor internal dan eksternal perusahaan sangat berpengaruh kuat terhadap PT Asuransi Jiwa Taspen. Dengan kekuatan, kelemahan, peluang dan ancaman yang terdapat di PT Asuransi Jiwa Taspen, manajemen harus memanfaatkan strategi SO yaitu memanfaatkan kekuatan terbesar untuk memanfaatkan peluang. Strategi alternatif SO yaitu; mempererat kemitraan dengan pemerintah dengan ketersediaan program asuransi untuk kebutuhan dari PNS, pengembangan distribusi pemasaran berupa pembukaan office chanelling di kantor cabang dalam rangka mengantisipasi pengembangan pasar dan meningkatkan kualitas dan kuantitas SDM.
\end{abstract}

Kata kunci: alternatif strategi, asuransi, asuransi jiwa, SWOT

\footnotetext{
${ }^{1}$ Corresponding author:

Email: sulastri.kurniawan@yahoo.co.id
} 


\section{PENDAHULUAN}

Perusahaan jasa memiliki karakteristik yang berbeda dengan perusahaan nonjasa (Kuntjoroadi dan Safitri, 2009). Asuransi adalah salah satu perusahaan yang bergerak dibidang jasa dan merupakan Lembaga Keuangan Non-Bank. Industri asuransi jiwa berhasil membukukan pertumbuhan positif di tengah melambatnya pertumbuhan ekonomi nasional. Penetrasi asuransi di Indonesia sebesar 2,1\% untuk total premi, sedangkan rata-rata dunia, Asia, dan ASEAN beturut-turut sebesar 6,28\%, 5,37\%, dan 3,35\%. Asosiasi Asuransi Jiwa Indonesia (AAJI)(2013) melaporkan perkembangan kinerja industri asuransi jiwa di tanah air sampai dengan kuartal ketiga 2015. Hasil laporan menunjukkan bahwa meski pertumbuhan perekonomian Indonesia masih melambat di sembilan bulan pertama tahun 2015, industri asuransi jiwa tetap membukukan kinerja positif. Akan tetapi pada kuartal ketiga 2015, terjadi penurunan hasil investasi asuransi sebesar $152,7 \%$. Hal tersebut disebabkan karena pelaku industri asuransi jiwa melakukan antisipasi dengan menempatkan investasinya pada portofolio yang lebih aman.

Menurut manajemen PT. Asuransi Jiwa Taspen, peluang perusahaan ini dalam pencapaian target yang ditetapkan akan sangat besar, akan tetapi hal tersebut belum maksimal dikarenakan adanya keterbatasan sarana, prasarana, dan sumber daya manusia dalam pengembangan pasar. Data nasabah PT Asuransi jiwa Taspen per Juni 2016 dibagi dalam 3 kategori, yaitu BUMN, PNS dan Umum, masing masing sebanyak 555.586 peserta dari 25 BUMN, 12.079 peserta dari PNS, dan 22.834 peserta dari umum. Jumlah nasabah tersebut masih sangat jauh dibandingkan populasi Pegawai di 119 BUMN dan data PNS dari Badan Pusat Statistik per tahun 2014 sebanyak 4,4 Juta di Indonesia.

Persaingan global dan peningkatan produktivitas menjadi isu penting apabila ingin mencapai keunggulan kompetitif yang berkelanjutan (sustainable competitive advantage) (Ellitan, 2006). Perusahaan yang berhasil adalah perusahaan yang melaksanakan konsep pemasaran yang berorientasi kepada konsumen (Suhartini, 2012). PT. Asuransi Jiwa Taspen yang merupakan perusahaan asuransi yang baru berdiri milik salah satu perusahaan BUMN sebagai tempat penelitian. Menurut manajemen PT. Asuransi Jiwa Taspen, peluang perusahaan ini dalam pencapaian target yang ditetapkan akan sangat besar. Akan tetapi, hal tersebut belum maksimal dikarenakan adanya keterbatasan fasilitas, sarana, prasarana, dan sumber daya manusia dalam pengembangan pasar.

Salim (2005) mengatakan bahwa asuransi adalah suatu kesediaan (oleh individu atau badan hukum) untuk menetepkan kerugian-kerugian kecil yang sudah pasti di masa sekarang sebagai pengganti kerugiankerugian besar yang belum pasti di masa datang. Menurut Asosiasi Asuransi Jiwa Indonesia (AAJI), produk asuransi jiwa adalah janji yang tertulis di dalam polis asuransi yang dibuat oleh penanggung kepada tertanggung untuk memberikan kompensasi keuangan apabila sesuatu terjadi kepada tertanggung. Terdapat beberapa jenis asuransi jiwa di Indonesia seperti ; Asuransi Jiwa Berjangka (Term Life), Asuransi Jiwa Seumur Hidup (Whole Life) dan Asuransi Jiwa Dwiguna (Endowment).

Kompetitor adalah faktor ancaman yang cukup penting dalam eksistensi perusahaan (Sidabutar, 2007). Kemunculan suatu produk yang sukses di pasar akan diikuti oleh para pesaingnya yang berjenis sama dengan produ-k tersebut, maka perlu adanya peningkatan dalam hal strategi pemasaran perusahaan agar tetap eksis di pasar, mencari laba yang maksimal dan tentunya mencapai visi misi perusahaan (Noor, 2014). Strategi adalah aksi potensi yang membutuhkan keputusan manajemen puncak dan sumberdaya perusahaan dalam jumlah yang besar. Selain itu, strategi memengaruhi perkembangan jangka panjang perusahaan karena berorientasi ke masa yang akan datang (David, 2011). Selain itu, strategi memengaruhi perkembangan jangka panjang perusahaan karena berorientasi ke masa yang akan datang.

Sebelum suatu perencanaan strategis dikembangkan manajemen puncak perlu menganalisis hubungan antara fungsi-fungsi manajemen perusahaan dengan mempelajari struktur perusahaan (Wibowo, 2009). Wijayanti (2010) berpendapat bahwa manajemen strategi yang semula tumbuh dan berkembang dalam dunia bisnis dan organisasi profit telah diterapkan ke dalam berbagai bentuk organisasi termasuk organisasi pemerintahan. Manajemen strategik merupakan serangkaian keputusan dan tindakan yang terarah dalam menyusun suatu strategi kebijakan yang efektif untuk membantu pencapaian sasaran suatu perusahaan atau organisasi (Wheelen dan Hunger, 2003). Terdapat tiga aktivitas mendasar dalam strategi, yaitu (1) peninjauan 
faktor eksternal dan internal yang mendasari strategi saat ini, (2) pengukuran kinerja dan (3) tindakan perbaikan (David, 2011). Menurut Oktaviana (2009) pada dasarnya penilaian strategi terdiri dari tiga hal yaitu peninjauan ulang faktor internal dan eksternal yang menjadi dasar bagi strategi yang sedang berlangsung, mengukur kinerja yang telah dilakukan dan mengambil berbagai tindakan perbaikan. Untuk membuat keputusan strategi akan yang dipilih diperlukan sebuah tata cara yang dikenal sebagai proses atau model manajemen strategi. Pembuatan tata cara ini dilakukan untuk menunjukkan adanya sebuah pendekatan yang jelas dan praktis secara komprehensif untuk menformulasi, mengimplementasi dan mengevaluasi strategi. Proses dan Model Manajemen Strategi memiliki tahapan-tahapan dalam pelaksanaannya dan dimulai dari pengamatan lingkungan, perumusan strategi, implementasi dan evaluasi/pegendalian

Sudah ada beberapa penelitian yang menyinggung beberapa hal yang dibahas dalam penelitian ini. Penelitian Saaty dan Ansari (2011) yang berjudul Factors Critical in Marketing Strategies of Insurance Companies in Saudi Arabia menghasilkan bahwa strategi perusahaan asuransi harus fokus pada strategi promosi. Penelitian menggunakan teknik statistik dengan menggunakan SPSS. Selain itu penelitian dari Prabowo (2003) yang berjudul Perencanaan Strategik Bisnis Asuransi Kerugian PT Asuransi X di Jakarta. Menggunakan alat analisis SWOT dan AHP. Hasil penelitiannya menghasilkan bahwa strategi utama PT Asuransi X adalah strategi pengembangan pasar atau strategi penetrasi pasar dan product development strategi atau strategi pengembangan produk.

Penelitian ini bertujuan mengidentifikasi dan mengkaji faktor-faktor internal dan eksternal yang berpengaruh terhadap eksistensi PT Asuransi Jiwa Taspen, mengetahui strategi PT Asuransi Jiwa Taspen dalam melakukan pengembangan pasar serta merekomendasikan strategi prioritas yang tepat dijalankan oleh PT Asuransi Jiwa Taspen. Ruang lingkup penelitian ini dibatasi dan difokuskan pada mengidentifikasi dan mengkaji faktor-faktor internal dan eksternal yang memengaruhi eksistensi PT Asuransi Jiwa Taspen dan Merekomendasikan strategi prioritas apa yang tepat bagi PT Asuransi Jiwa Taspen.

\section{METODE PENELITIAN}

Penelitian dilakukan di Kantor Pusat PT Asuransi Jiwa Taspen yang bergerak pada bidang usaha asuransi jiwa. Waktu penelitian lima bulan dari bulan Agustus 2016 sampai dengan Oktober 2016. Data yang digunakan terdiri dari dua jenis data yaitu data primer dan data sekunder. Data primer merupakan data yang didapatkan melalui hasil Focus Group Discussion (FGD) dan wawacara (in-dept interview) melalui kuesioner. Hasil yang didapatkan dari data primer ini digunakan oleh peneliti untuk menjawab tujuan penelitian yang telah dirumuskan (Sumarwan, 2011). Untuk identifikasi faktor internal dan eksternal meliputi tingkat keterlibatan stakeholder dalam pengelolaan operasional. Data sekunder elektronik serta informasi lain yang berhubungan dengan topik penelitian.

Pengumpulan data dilakukan dengan menggunakan beberapa teknik Observasi, wawancara mendalam (in-depth interview), kuesioner dan studi pustaka. In-depth interview dilakukan kepada manajemen PT Asuransi Jiwa Taspen untuk mengetahui informasi lebih mendalam mengenai faktor strategis internal yang mempengaruhi pengembangan bisnis. Studi pustaka dilakukan dengan cara mempelajari dan memahami buku-buku yang berkaitan dengan teori dan praktek yang digunakan dalam penelitian, serta peneliti terdahulu yang berkaitan dengan topik penelitian.

Metode Penelitian yang digunakan adalah metode diskriptif dengan penelitian menggunakan focus group discussion. Metode deskriptif yaitu metode pengumpulan data yang dilakukan untuk menjawab permasalahan yang ada dengan metode pendekatan studi kasus. Metode deskriptif ini bertujuan menjelaskan fakta dan populasi dari suatu permasalahan tertentu pada perusahaan atau organisasi atau lingkungan secara faktual dan sistematis. Hal tersebut dilakukan dengan cara wawancara dengan alat bantu kuisioner terhadap lingkungan internal yaitu manajemen dari PT Asuransi Jiwa Taspen dan berbagai stakeholder sebagai responden eksternal. Wawancara dan alat bantu kuisioner dilakukan untuk mengidentifikasi harapan para stakeholder, mengevaluasi visi dan misi, serta mengidentifikasi faktor internal dan eksternal.

Untuk identifikasi faktor internal dan eksternal dapat menggunakan formulasi strategi dan pemilihan strategi yang dilakukan dengan menggunakan metode pusposive sampling. Populasi penelitian adalah manajemen dan 
nasabah PT Asuransi Jiwa Taspen. Sampel untuk kuesioner SWOT berjumlah 19 orang,

Dalam membuat suatu alternatif formulasi strategi, maka langkah awal yang harus dilakukan adalah melihat visi dan misi dari perusahaan. Tahap berikutnya adalah melakukan perumusan manajemen strategi. Pada tahap ini, kondisi perusahaan dapat dilihat dalam 4 perspektif, yaitu perspektif keuangan, perspektif nasabah, perspektif proses bisnis internal, dan perspektif pembelajaran dan pertumbuhan.

Tahap selanjutnya adalah dengan melakukan analisis situasi perusahaan baik internal maupun eksternal. Tujuan dari analisis situasi adalah untuk mengetahui posisi perusahaan saat ini dan mengetahui daya tarik Industri. Analisis internal dimaksudkan untuk mengembangkan daftar kekuatan yang dapat dimanfaatkan oleh perusahaan untuk mengatasi kelemahannya, mencakup bagian-bagian fungsional seperti produksi, keuangan, pemasaran, manajemen, dan sumber daya manusia. Hasil analisis internal disajikan dalam bentuk matriks IFE yang memuat daftar kekuatan dan kelemahan perusahaan disertai hasil penilaian pihak responden.

Analisis eksternal terdiri atas analisis lingkungan industri untuk mengetahui situasi dalam industri dan tingkat kompetisi di dalamnya, serta analisis lingkungan makro seperti politik, ekonomi, sosial-budaya, dan teknologi. Kepentingan analisis lingkungan eksternal antara lain untuk memprediksi pergerakan para pesaing, kekuatan persaingan, faktor-faktor penentu/ kunci kesuksesan (key success factors). Seperti halnya pada analisis internal, hasil analisis eksternal yang berupa daftar sejumlah peluang ancaman yang perlu diperhatikan kemudian disusun dalam bentuk matriks EFE.

Kerangka pemikiran penelitian tentang variabelvariabel apa saja yang diturunkan dari konsep terpilih dan bagaimana hubungan diantara variabel-variabel tersebut serta hal apa saja yang menjadi indikator untuk mengukur variabel-variabel yang bersangkutan. Langkah awal yang harus dilakukan peneliti adalah dengan melihat visi dan misi dari perusahaan. Hal tersebut sangat penting karena dari visi misi dapat tergambar dengan jelas arah tujuan dari perusahaan. Dalam penelitian ini, tahapan pertama yang dilakukan oleh peneliti adalah mengumpulkan gambaran umum lingkungan internal dan eksternal perusahaan dengan populasi penelitian di manajemen dan nasabah PT Asuransi Jiwa Taspen menggunakan cara observasi dan wawancara. Tahapan kedua adalah analisis internal dan eksternal perusahaan dengan tujuan dari analisis situasi adalah untuk mengetahui posisi perusahaan saat ini. Tahapan ketiga adalah analisa SWOT untuk mengidentifikasi berbagai faktor secara sistematis untuk merumuskan strategi perusahaan dengan cara melakukan penyebaran kuesioner ke internal dan eksternal perusahaan. Tahapan terakhir yang dilalukan peneliti melalui perumusan alternatif strategi yang diambil dari bobot tertinggi dari hasil pengolahan dalam analisis SWOT. Kerangka pemikiran penelitian selengkapnya pada Gambar 1.

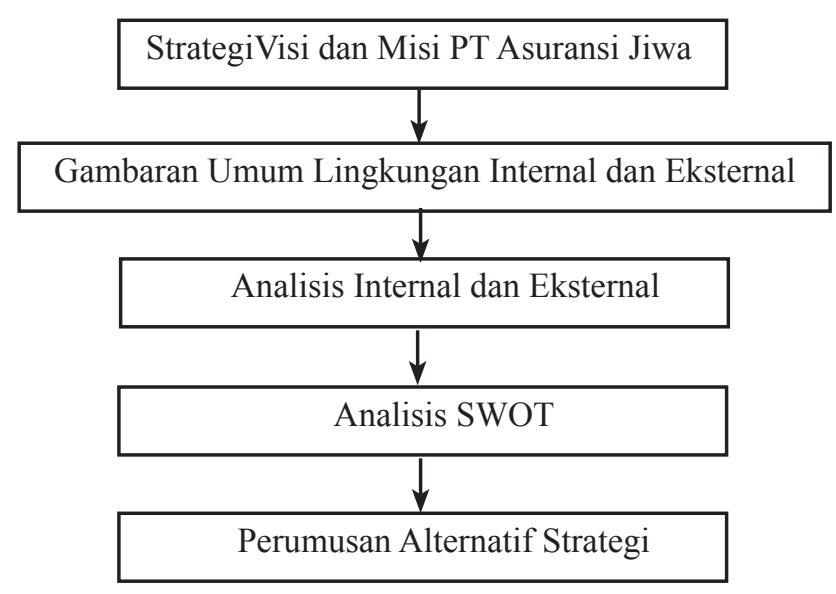

Gambar 3. Kerangka pemikiran penelitian 


\section{HASIL}

\section{Identifikasi Faktor Internal dan Eksternal}

Analisis terhadap faktor internal dilakukan untuk mengetahui faktor-faktor dari dalam perusahaan baik yang menjadi kekuatan maupun kelemahan dari perusahaan itu sendiri. Terdapat total 10 faktor internal di PT Asuransi Jiwa Taspen, 6 faktor kekuatan (strength) dan 4 faktor kelemahan (weaknesess). Pada matrik analisis internal, skor terbobot yang dihasilkan untuk kekuatan adalah sebesar 2,08 dan kelemahan adalah sebesar 0,6 yang menunjukkan bahwa posisi internal PT Asuransi Jiwa Taspen kuat. Perusahaan butuh mempertahankan dan lebih meningkatkan dengan memanfaatkan kekuatan yang ada dan mengatasi segala kelemahannya dengan baik. Hasil matriks Internal Faktor selengkapnya dapat dilihat pada Tabel 2.

Analisis terhadap faktor eksternal dilakukan untuk mengetahui faktor-faktor dari luar perusahaan yang terdiri dari peluang dan ancaman. Terdapat total 11 faktor internal di PT Asuransi Jiwa Taspen, 6 faktor Peluang dan 5 faktor ancaman. Analisis matriks Exsternal Factor Evaluation (EFE) menghasilkan skor terbobot (weight score) sebesar 3,09 yang terdiri dari total peluang 1,96 dan total ancaman adalah 1,12. Hal ini berarti bahwa PT Asuransi Jiwa Taspen mampu dan kuat kuat dikarenakan peluang lebih besar dari pada ancaman. Perusahaan butuh mempertahankan dan lebih meningkatkan dengan memanfaatkan peluang yang ada dan mengatasi segala ancamanya dengan baik. sHasil matriks faktor eksternal selengkapnya dapat dilihat pada Tabel 3.

Secara ringkas hasil perumusan matriks IFAS - EFAS, berdasarkan strategi SO, ST, WO, dan WT, dilakukan pembobotan penilaian untuk menentukan skala prioritasnya. Susunan strategi alternatif berdasarkan urutan prioritasnya yang diperoleh dari pembobotan matriks interaksi SWOT disajikan pada Gambar 2.

Hasil interaksi IFAS - EFAS yang menghasilkan alternatif strategi yang mendapat bobot paling tinggi adalah Strength - Opportunity (SO), yang dapat diterjemahkan sebagai strategi menggunakan kekuatan untuk memanfaatkan peluang/kesempatan yang ada. Kondisi ini menguntungkan bagi PT Asuransi Jiwa Taspen, karena dari sisi internal, perusahaan memiliki potensi dan kekuatan yang lebih besar dari kelemahannya. Dari sisi ekternalnya, peluang pengembangan perusahaan berjalan dengan seimbang, meski peluang lebih besar nilainya daripada ancaman. Perumusan strategi diperolah melalui hasil beberapa kombinasi strategi.

Tabel 2. Faktor internal di PT Asuransi Jiwa Taspen

\begin{tabular}{|c|c|c|c|}
\hline Faktor-faktor internal & Bobot & Rating & $\begin{array}{l}\text { Weight } \\
\text { Score }\end{array}$ \\
\hline \multicolumn{4}{|l|}{ Kekuatan } \\
\hline Kemitraan dengan Pemerintah dalam pengelolaan TOP UP THT bagi PNS dan pejabat negara & 0,10 & 4 & 0,41 \\
\hline $\begin{array}{l}\text { Pengembangan distribusi pemasaran berupa pembukaan Office Channelling di kantor cabang } \\
\text { PT Taspen (Persero) }\end{array}$ & 0,09 & 3 & 0,27 \\
\hline Ketersediaan dukungan modal perusahaan yang sangat kuat dari induk perusahaan & 0,09 & 4 & 0,38 \\
\hline Adanya produk asuransi atau program tambahan yang bervariasi & 0,11 & 3 & 0,33 \\
\hline $\begin{array}{l}\text { Kualitas SDM Marketing dalam memasarkan produk asuransi endowment dan individu yang } \\
\text { baik }\end{array}$ & 0,10 & 4 & 0,38 \\
\hline $\begin{array}{l}\text { Pengelolaan investasi yang tepat dan akurat dalam hal jangka waktu dan penempatan } \\
\text { investasi }\end{array}$ & 0,11 & 3 & 0,32 \\
\hline Total kekuatan & & & 2,08 \\
\hline \multicolumn{4}{|l|}{ Kelemahan } \\
\hline Kurang memadainya sistem komputerisasi perusahaan & 0,09 & 2 & 0,19 \\
\hline Keterbatasan keterampilan dan jumlah SDM di perusahaan sesuai kebutuhan & 0,10 & 2 & 0,20 \\
\hline Kuantitas jaringan distribusi yang masih sedikit pada pemasaran produk asuransi individu & 0,11 & 1 & 0,11 \\
\hline Kualitas kebijakan dan peraturan internal perusahaan yang kurang kuat & 0,10 & 1 & 0,10 \\
\hline Total kelemahan & & & 0,60 \\
\hline Total & 1 & & 2,68 \\
\hline
\end{tabular}


Tabel 3. Faktor eksternal di PT Asuransi Jiwa Taspen

\begin{tabular}{|c|c|c|c|}
\hline Faktor-faktor eksternal & Bobot & Rating & $\begin{array}{l}\text { Weight } \\
\text { Score }\end{array}$ \\
\hline \multicolumn{4}{|l|}{ Peluang } \\
\hline Jumlah benefit asuransi yang diterima PNS masih kurang & 0,09 & 4 & 0,37 \\
\hline $\begin{array}{l}\text { Jumlah Pemegang Polis masih sedikit dibanding dengan potensi pasar dan jumlah penduduk } \\
\text { yang ada }\end{array}$ & 0,08 & 3 & 0,25 \\
\hline Tingginya pertumbuhan pasar asuransi jiwa beberapa tahun terakhir & 0,09 & 4 & 0,34 \\
\hline $\begin{array}{l}\text { Ketersediaan asuransi untuk pengelolaan dana kesejahteraan pegawai aktif dan pensiun yang } \\
\text { lengkap }\end{array}$ & 0,08 & 4 & 0,33 \\
\hline Peraturan Pemerintah dan Peraturan Menteri BUMN & 0,10 & 4 & 0,40 \\
\hline $\begin{array}{l}\text { Pengelolaan investasi yang tepat dan akurat dalam hal jangka waktu dan penempatan } \\
\text { investasi }\end{array}$ & 0,09 & 3 & 0,26 \\
\hline Total peluang & & & 1,96 \\
\hline \multicolumn{4}{|l|}{ Ancaman } \\
\hline $\begin{array}{l}\text { Banyaknya keberadaan perusahaan joint venture yang telah mapan dengan teknologi dan } \\
\text { SDM nya, serta perusahaan asuransi jiwa nasional yang semakin eksis di industri }\end{array}$ & 0,10 & 4 & 0,39 \\
\hline $\begin{array}{l}\text { Banyaknya keberadaan produk-produk subtitusi (asuransi kecelakaan) yang dikeluarkan oleh } \\
\text { perusahaan asuransi kerugian (bekerja sama dengan perbankan) }\end{array}$ & 0,09 & 2 & 0,17 \\
\hline Banyaknya iuran premi BUMN ditanggung peserta & 0,09 & 3 & 0,27 \\
\hline Pemahaman masyarakat tentang benefit dari asuransi individu masih kurang & 0,10 & 2 & 0,21 \\
\hline Kondisi nilai saham dan nilai tukar rupiah terhadap dollar masih lemah & 0,09 & 1 & 0,09 \\
\hline Total Ancaman & & & 1,12 \\
\hline Total & 1 & & 3,09 \\
\hline
\end{tabular}

\begin{tabular}{|l|l|l|}
\cline { 2 - 3 } \multicolumn{1}{c|}{} & $\mathrm{S}=2,08$ & $\mathrm{~W}=0,60$ \\
\hline $\mathrm{O}=1,96$ & $\mathrm{SO}=4,04$ & $\mathrm{WO}=2,56$ \\
\hline $\mathrm{T}=1,12$ & $\mathrm{ST}=3,20$ & $\mathrm{WT}=1,72$ \\
\hline
\end{tabular}

Gambar 2. Pembobotan Matrik SWOT

\section{Analisis SWOT}

Setelah melakukan analisis eksternal dan internal, data-data lalu dikelompokkan dan dianalisis menjadi faktor-faktor SWOT ke dalam matriks SWOT. Matriks SWOT adalah langkah-langkah konkrit yang harus dilakukan oleh PT Asuransi Jiwa Taspen berdasarkan pengembangan daristrategiSO. Melaluimatriks SWOT, strategi SO (strength-opportunity) dapat dirumuskan menjadi 3 strategi, yaitu mempererat Kemitraan dengan Pemerintah dengan ketersediaan program asuransi untuk kebutuhan dari PNS; pengembangan distribusi pemasaran berupa pembukaan office chanelling di kantor cabang dalam rangka mengantisipasi pengembangan pasar; meningkatkan kualitas dan kuantitas SDM.

\section{Rumusan Alternatif Strategi}

Hasil dari analisis SWOT, strategi yang direkomendasikan pada strategi SO adalah mempererat Kemitraan dengan Pemerintah dengan ketersediaan program asuransi untuk kebutuhan dari PNS, mengembangkan distribusi pemasaran berupa pembukaan office chanelling di kantor cabang dalam rangka mengantisipasi pengembangan pasar dan meningkatkan kualitas dan kuantitas SDM. Strategi ini dijalankan untuk memaksimalkan potensi perusahaan untuk memanfaatkan peluang pasar. Perusahaan dapat fokus pada penanganan nasabah mulai dari akuisisi konsumen sampai memelihara konsumen yang telah menggunakan produk asuransi PT Asuransi Jiwa Taspen dalam rangka meningkatkan jumlah nasabah. PT Asuransi Jiwa Taspen dapat memfokuskan strategi pemeliharaan konsumen pada pemeliharaan kemitraan dengan Pemerinah yang dalam hal ini bertindak sebagai mitra bisnis sehingga Pemerintah dapat melakukan sinergi BUMN dalam hal pengadaan asuransi, kemitraan dengan Pemerintah dalam pengelolaan TOP UP THT bagi PNS dan pejabat negara dan produk atau pelayanan lain untuk PNS. Strategi akuisisi dilakukan dengan tujuan meningkatkan market share dari produk asuransi PT Asuransi Jiwa Taspen 
pada pasar yang ada saat ini melalui usaha-usaha pemasaran yang lebih gencar. Strategi pengembangan pasar melalui akuisisi konsumen ini paling sering digunakan dan dikombinasikan dengan strategi lain. Cara melaksanakan strategi akuisisi konsumen dengan mengembangkan distribusi pemasaran berupa pembukaan office chanelling di kantor cabang serta meningkatkan kualitas dan kuantitas SDM dalam rangka mengantisipasi pengembangan pasar. Kualitas dan kuantitas SDM menjadi perhatian karena seiring dengan berkembangnya industri asuransi sekarang ini, kemungkinan besar tantangan pasar juga akan semakin luas dan hal tersebut memerlukan SDM yang tidak sedikit dan berkompeten di bidangnya. Berdasarkan hasil analisis, strategi SO merupakan alternatif strategi terbaik yang memiliki nilai pembobotan yang paling tinggi, namun untuk belum tentu semua strategi tersebut dapat dilaksanakan secara simultan, sehingga perlu dilakukan prioritas apabila dalam pelaksanaannya secara bersama-sama menemui kendala sumber daya (resources constraints). Penentuan prioritas kebijakan dari beberapa strategi kebijakan Strength - Opportunity (SO) yang dihasilkan melalui analisis SWOT.

\section{Implikasi Manajerial}

Faktor internal dan eksternal perusahaan sangat berpengaruh kuat terhadap PT Asuransi Jiwa Taspen. Dengan kekuatan, kelemahan, peluang dan ancaman yang terdapat di PT Asuransi Jiwa Taspen, manajemen harus memanfaatkan strategi SO yaitu memanfaatkan kekuatanterbesaruntuk memanfaatkan peluang. Strategi alternatif SO yaitu mempererat kemitraan dengan pemerintah dengan ketersediaan program asuransi untuk kebutuhan dari PNS, pengembangan distribusi pemasaran berupa pembukaan office chanelling di kantor cabang dalam rangka mengantisipasi pengembangan pasar dan meningkatkan kualitas dan kuantitas SDM.

\section{KESIMPULAN DAN SARAN}

\section{Kesimpulan}

Hasil penelitian SWOT, terdapat 10 faktor internal dan 11 faktor eksternal yang memengaruhi eksistensi perusahaan yang terdiri dari 6 faktor kekuatan, 4 faktor kelemahan, 6 faktor peluang dan 5 faktor ancaman. Selanjutnya, strategi SO merupakan alternatif strategi terbaik yang dapat digunakan untuk pengembangan perusahaan, yang meliputi mempererat kemitraan dengan pemerintah dengan ketersediaan program asuransi untuk kebutuhan dari PNS, mengembangkan distribusi pemasaran berupa pembukaan office chanelling di kantor cabang dalam rangka mengantisipasi pengembangan pasar dan meningkatkan kualitas dan kuantitas SDM.

\section{Saran}

Hasil penelitian yang dilakukan, terdapat beberapa saran untuk perusahaan diharapkan dapat menggunakan strategi hasil analisis yang dilakukan oleh peneliti. Strategi tersebut didapat berdasarkan hasil dari uji analisis faktor-faktor internal dan eksternal perusahaan. Selain itu, strategi yang masih berjalan tetap harus dikembangkan seiring dengan perkembangan pasar dan teknologi. Perusahaan dapat memenuhi kriteria implikasi manajerial yang diajukan, meliputi; penetapan rencana anggaran untuk mendukung pelaksanaan strategi prioritas perusahaan dan pembuatan program dan meningkatkan kegiatan yang bermanfaat untuk SDM di Perusahaan yang mencakup; membuat budaya kerjayang baikdilingkungan perusahaan, meningkatkan pendidikan dan pelatihan yang bertujuan meningkatkan pengetahuan, keterampilan dan sikap, memberikan penghargaan atas prestasi dan promosi kepada SDM di pemasaran untuk meningkatkan semangat kerja dan peningkatan karir serta merekrut karyawan yang diarahkan pada pengembangan pasar dan pelayanan konsumen. Perusahaan dapat melakukan studi banding dengan kompetitor atau perusahaan sejenis untuk mencari benchmark dalam rangka memperoleh informasi dan menambah pengetahuan tentang strategi yang dilakukan oleh perusahaan asuransi lain. Penelitian selanjutnya dapat dilakukan dengan melanjutkan meneliti seputaran evaluasi terhadap strategi alternatif dan pengembangan perusahaan PT Asuransi Jiwa Taspen.

\section{DAFTAR PUSTAKA}

[AAJI] Asosiasi Asurasni Jiwa Indonesia. 2013. Pedoman asuransi Jiwa. www.aaji.or.id/ infocenter/guidelines.aspx [18 Agustus 2016].

David R. 2011. Manajemen Strategis. Jakarta: Penerbit Salemba Empat.

Ellitan L. 2006. Strategi inovasi dan kinerja perusahaan manufaktur di Indonesia: pendekatan model simultan dan model sikuensi. Jurnal Manajemen 
$1(6): 1-22$.

Kuntjoroadi W, Safitri N. 2009. Analisis strategi bersaing dalam persaingan usaha penerbangan komersial. Jurnal Ilmu Administrasi dan Organisasi 16(1):45-52.

Noor S. 2014. Penerapan analisis SWOT dalam menentukan strategi pemasaran Daihatsu Luxio di Malang (studi kasus pada PT. astra International Tbk - Daihatsu Malang). Jurnal INTEKNA 14(2):1-9.

Oktavina R. 2009. Model manajemen strategis evaluasi kinerja usaha mikro dan kecil makanan ringan. Jurnal Ekonomi Bisnis 2(14):88-98.

Prabowo A. 2003. Perencanaan Strategi Bisnis Asuransi Kerugian PT Asuransi "X" di Jakarta [tesis]. Bogor: Institut Pertanian Bogor.

Saaty AS, Ansari ZA. 2011. Factor critical in marketing strategies of insurance companies in Saudi Arabia. International Journal of Markrting studies 3(3):104-121.
Salim A. 2005. Asuransi dan Manajemen Resiko. Jakarta: PT Rajagrafindo Persada.

Sidabutar H. 2007. Perancangan arsitektur strategik di perusahaan furniture panel wood PT Cahaya Sakti Furintraco [tesis]. Bogor: MMA-IPB.

Suhartini. 2012. Analisis SWOT dalam menentukan strategi pemasaran pada perusahaan. MATRIK $7(2): 1-7$.

Wheelen TL, Hunger JD. 2012. Strategic Manajement and Business Policy. 13th Ed. New Jersey: Pearson International.

Wibowo W. 2009. Analisis internal \& eksternal (IE) matrik dalam strategi pengembangan objek wana wisata Grajagan. Jurnal Ekonomi Bisnis 14(2):161-170.

Wijayanti DT. 2010. Faktor-faktor yang memengaruhi manajemen strategic pada organisasi non profit (studi manajemen strategic pada Dinas Propinsi Jawa Timur). Jurnal Manajemen dan Kewirausahaan 12(1): 24-32. 